\title{
Technical Education, Vocational Training and Industrialisation in Sub- Saharan Africa(SSA)
}

\author{
Benedicte D'almeida Ngah Atangana ${ }^{1} \&$ Henri Ngoa Tabi $^{1}$ \\ ${ }^{1}$ Faculty of Economics, University of Yaounde II, Cameroon \\ Correspondence: Benedicte D'almeida Ngah Atangana, Faculty of Economics, University of Yaounde II, \\ Cameroon. E-mail: up202103969@edu.fep.up.pt
}

Received: November 17, 2021

doi:10.5539/jsd.v15n1p65
Accepted: January 12, $2022 \quad$ Online Published: January 14, 2022

URL: https://doi.org/10.5539/jsd.v15n1p65

\begin{abstract}
This study contributes to a deeper understanding and perspective on the current debate on structural transformation in Sub-Saharan Africa (SSA) by investigating the effect of technical vocational education and training on industrial performance between 1980 - 2018. The panel data used for this study were obtained from World Development Indicators (WDI), International Labour Organization (ILO), United Nations Educational, Social and Cultural Organization (UNESCO) and Fraser Institute databases. The empirical results derived from the Instrumental Variable (IV) Two-Stage Least Squares (2-SLS) econometric approach highlighted the important role of Technical Vocational Education and Training (TVET) as key determinants of industrial performance in SSA. The study found strong and robust relationship between TVET and measures of industrialisation. General secondary education, on the other hand, had a negative effect on industrialisation in SSA. The paper recommends therefore that there is the need for a complete overhaul and revision of the educational system in SSA with more emphasis on TVET in order to meet the required labour demand for industrial needs in the foreseable future.
\end{abstract}

Keywords: industrialisation, technical vocational education and training, general education, structural transformation

\section{Introduction}

Structural transformation is viewed as an indispensable pathway to sustainable and inclusive economic growth. The classical meaning of structural transformation, as defined by (Lewis, 1954) and (Kuznets, 1957) refers to the shift of population and economic activity from agriculture to industry, and later to services (Kanbur, 2017). Since productivity is higher in manufacturing than in agriculture, the shift of resources to this sector would normally provide the basis for higher rates of growth induced by the productivity difference (Oyelaran-Oyeyinka \& Lal, 2016).

Indeed, for (Chandra, 2003), industrialisation can be defined as the increase in the value added of the manufacturing sector as a percentage of GDP. In this regard, the achievement of industrialisation implies a faster growth registered in the manufacturing sector relative to other sectors. For (Echaudemaison, 2003) industrialisation is observed through the increase in the share of the secondary sector in terms of employment generation and strong GDP growth. However, the central dynamic force behind the industrial revolution has been attributed to innovation (Kuznets, 1957), and each industrial revolution has its own distinctive innovation that raises the skills of the workforce.

Since 2005, several African countries have made significant progress in maintaining positive growth and improving their performance on social indicators such as health and education. The volume of real GDP grew on the continent by 54\% between 2004 and 2014, more than twice the world average of $24 \%$ (CNUCED, 2016). However, growth in most African countries has not been inclusive and trends in socio-economic indicators (poverty, unemployment etc.) are mixed. High dependence on primary commodity exports and limited value addition characterised the challenges faced by most African countries associated with limited success in achieving economic diversification and industrialisation.

However, the experience of now industrialised countries shows that technical vocational education and training (TVET) plays an important role in the production of skilled personnel working in small and medium enterprises (Han, 1994). Sub-Saharan Africa, which has the youngest population in the world and a population growth rate of 
$2.7 \%$ since the 2000 s, should exploit and enhance its human capital development for its industrialisation and economic diversification needs.

To this end, the Economic Commission for Africa Report (CEA, 2020) points out that in the case of central African countries, the structure of the training offered was not in line with the objectives of diversification and industrialisation. Thus, the region needs 4.3 million engineers and 1.6 million agronomists to meet their industrialisation needs It is surprising to note that these countries are striving to produce $80 \%$ of graduates in social sciences and humanities each year (African Development Bank, 2017). Therefore, there is an urgent need to question the appropriateness of the educational systems curretly being implemented in most Africa countries.

In South Korea, for example, the role of education has been crucial in its industrialisation process. There was a perfect coordination between the education system and the industrial sector. It is worthnoted that in the 1970s, the economic policy and management strategy of South Korea emphasised much on capital-intensive technology, heavy and chemical industries, the construction of technical colleges and engineering schools were built to meet the corresponding labour demand. While in the 1980s, technology-intensive education was emphasised, the focus was on higher education at the university and college levels (Han, 1994). Why not follow the example of these countries and take advantage of the potential benefits that TVET can offer to Sub-Saharan African countries to promote industrialisation in these economies? The empirical studies examining the link between TVET and industrialisation in Sub-Saharan Africa remained scanty. This study was primarily designed to fill this gap in the literature on Africa accordingly.

The rest of the paper is structured as follows: Section two reviews critically the theoretical and empirical literature on TVET. Section three also analyses the dynamics of the industrial sector in SSA while section four highlights the methodology, section five is devoted to the discussion of the estimated model results. Finally, the model results section six as well as the conclusion from the study based of the empirircal findings.

\section{Literature Review}

This section presents a review of both theoretical and empirical literature on the effect of technical and vocational education and training on industrialisation.

\subsection{Theoretical Literature Review}

Basic classical theories of economic development based on industrialisation, such as those of (Rosenstein-Rodan, 1943), (Kaldor, 1967; Murphy et al., 1989) emphasised the key advantages of manufacturing over services in the form of economies of scale, backward and forward linkages and innovation potential. The role of the superentrepreneur in achieving a style 'big push' is fundamental (Rosenstein-Rodan, 1943). The author proposes the strategy of balanced growth and defends the rational for the big push. For the rapid and irreversible industrial development of these pre-capitalist countries, a massive intervention (a strong impulse) by the state was necessary. $\mathrm{He}$ asserted that at the beginning of the industrialisation process it is necessary to create several industrial units at the same time, in the majority of the branches of industry, this will make it possible to recruit massively in order to ensure a solvent demand for all the companies (without which they will not go far) and to offer the raw material to all these companies, some of which are located upstream of the others.

On the other hand, authors such as (Hirschman, 1958) and (Baumol, 1967) emphasised the potentially unbalanced nature of growth resulting from a difference in productivity between sectors. According to this doctrine, all the state has to do is to create a first industrial unit in a strategic branch (the one with the most backward and forward links with the other branches) and all the other branches will develop because businessmen will seize the opportunities that arise to create companies in the other backward and forward branches. In his "Cost Disease of Services" theory, Baumol explains the difference in productivity between the goods and services sectors. Indeed, with both sectors competing for factors of production in the same market, the relative costs of producing services increase. In other words, if the productivity of an individual in different tasks is uncorrelated or, in the worst case, weakly correlated, then individuals with a comparative advantage in one sector will also have, on average, an absolute advantage in that sector. The more other sectors of the economy develop, the more they will attract potential workers with a low comparative advantage and a low absolute advantage over the existing sectors of the economy, while leaving individuals with a high productivity in these sectors. As a result, productivity in expanding sectors will appear to be falling, while productivity in contracting sectors will appear to be rising.

Thus, one of the enduring stylised facts of economic development is that low-income countries have large differences in output per worker across sectors. Structural transformation, that is, the transfer of resources from low productivity sectors to higher productivity sectors, is therefore often a key factor in growth (Chenery et al., 1986; Lewis, 1954). During the process of structural transformation, changes in output per worker across the 
economy are the result of labour productivity growth in individual sectors and the variation in labour productivity due to reallocations of labour between sectors. When high productivity growth within a sector is combined with rapid movement of labour to higher productivity sectors, very rapid growth in output per worker is possible (McMillan \& Rodrik, 2011).

(Schultz, 1963) and (Becker, 1964) point out that developing countries, in order to grow rapidly, need not only equipment and workers in quantity, but also human capital in quantity and quality. Human capital refers to the education and health of workers. These authors explained the economic rationality that governs the accumulation of human capital (especially education) among agents. Education is an investment. Agents, in their microeconomic behaviour, decide on this investment according to the prospects of technological change. At the macroeconomic level, the stock and structure of human capital are therefore to a very large extent the consequence of microeconomic decisions, and only to a small extent the result of public policies. Hence, the need for state intervention to promote the realisation of the stock and composition of human capital that can accelerate economic growth. But, like physical capital, if accumulated human capital is not used effectively, it will not have the desired effect. More often than not, developing countries invest in training workers they do not use, for example, in Central Africa produces $80 \%$ of social science and humanities graduates each year (African Development Bank, 2017). However, the experience of today's industrialised countries shows that technical and vocational education and training (TVET) plays an important role in the production of skilled personnel needed in the industrialisation process (Han, 1994).

To this end, (Foster, 1965) was the first to raise the necessity of TVET for the industrialisation needs of newly independent economies. However, the policy and research orthodoxies in favour of general education were dominant in the 1980s (Psacharopoulos \& Loxley, 1985). Indeed, (Psacharopoulos, 1994; Psacharopoulos \& Loxley, 1985) studies are the best known in favour of investment in TVET, which became the donor orthodoxy in the 1990s. In this literature, TVET has been shown to offer much lower returns than primary or general secondary education. The apparent strength of the evidence at the global level was such that little solid empirical work was done on the subject in Africa.

Despite Psacharopoulos' claims, based on global surveys, early studies in Africa (Grootaert, 1990; Hinchliffe, 1990) showed that the returns to TVET are high. Indeed, Grootaert's (1990) work was particularly important in suggesting that informal training could produce very high rates of return, which is consistent with non-econometric work by African researchers such as (Fluitman, 1992) in west Africa. Subsequent work in east Africa by Kahyarara and Teal (2008) confirms this. Indeed, using data from the fourth and fifth rounds of the Tanzania manufacturing sector survey, the authors find that high levels of academic education have much higher returns than either TVET or lower levels of academic education. However, at lower levels of education, the returns to TVET can exceed those to academic training.

\subsection{Review of the Empirical Literature}

Several empirical studies have explained the difference in productivity between sectors and the effect of education on industrialization. For example, using the general equilibrium model in a two-sector post-war US economy, Acemoglu and Guerrieri (2008) showed that the interaction between capital deepening and differences in factor shares across sectors led to unbalanced growth, while being consistent with Kaldor's set of facts. In other words, capital-rich sectors had higher productivity than high-skilled labour-rich sectors because in the former, capital was a substitute for low-skilled labour. However, at the aggregate level the capital/output ratio remained stable as argued by Kaldor.

Also, using a calibrated model, Chen (2020) found that $2 / 3$ of the productivity difference in the post-war United States was explained by capital accumulation and its interaction with capital-skill complementarity. Indeed, for Chen, capital-skill complementarity justifies the difference in productivity between sectors. In the goods sector (agriculture and manufacturing) rich in low-skilled labour, capital was a substitute for labour. In the service sector, which is rich in high-skilled labour, capital was a complement to labour. This rationalised the high level of productivity in the goods sector relative to the services sector. Similarly, Ongo Nkoa (2016) using a system GMM method on data from 1975-2014 on 53 countries in Africa, finds that human capital (measured by the gross secondary school enrolment rate) increases Africa's industrialisation. This was because a high level of education allowed for faster absorption of new technologies and efficient output. Totouom et al. (2019) on a sample of 45 SSA countries between period 1997-2016 finds that human capital had a positive effect on industrialisation because it increased the supply of skilled workers, which attracted industrial investment.

With regard to the specific case of TVET, Backes-Gellner and Lehnert (2021) show that, despite the idea that quality innovation requires university-educated workers, some countries such as Switzerland and Germany with 
strong TVET systems are still among the best in international innovation rankings, outperforming countries with much higher percentages of students with tertiary-level degrees acquired only through university education. The TVET programmes are dual, i.e. they consist of upper secondary level learning programmes, which combine about three quarters on-the-job training and one quarter vocational education. Almost $70 \%$ of workers in Germany or Switzerland are TVET graduates (Backes-Gellner \& Lehnert, 2021). Rosina et al. (2021) conducted a study on the quality of TVET needed for industrialisation purposes in Indonesia. The results of this study showed that vocational schools in Indonesia need to produce graduates with soft skills and hard skills that match the needs of industries. The role of teachers in the industrialisation process is also very important. Indeed, teachers who have direct experience in industry will be of great help to future graduates (Oke \& Fernandes, 2020).

In the case of Finland, Silliman and Virtanen (2022) study the labour market returns to vocational education compared to general secondary education using a regression discontinuity model created by the centralised admission process and find a greater return of TVET. However, Oketch (2014) discussed the failed attempts to professionalise school curricula in Ghana and Kenya from the late 1980s onwards, with the idea that this would simultaneously reduce youth unemployment, provided an alternative education for those who do not succeed in mainstream education, and support innovation and economic development. However, it was found that performance of TVET compared to general education seems inconclusive. Studies such as Hanushek et al. (2017) in particular, using the difference-in-difference method on microdata from 11 countries of the International Adult Literacy Survey (IALS) have shown that the initial advantage of TVET in the labour market decreases with age.

On the other hand, a large body of empirical literature argued that limited skills were the key to the poor performance of African countries, particularly their manufacturing enterprises (Pack, 2002). The central premise of much of this discussion was that skills markets do not work and that it was necessary to subsidise firms to ensure training. Allais (2020) examined three interrelated factors outside the formal provision of TVET in sub-Saharan Africa that have undermined TVET systems. The first is the process, pace and level of industrialisation, which has had a direct effect on the supply of TVET and few well-paid jobs requiring technical expertise. This had an indirect effect, which is the second crucial factor. In fact, in the absence of economic development and change in labour markets, most people are in survival jobs. An international consensus since the 2000s on palliative approaches to development, which addressed the effects but not the causes of the lack of economic development in Africa, has resulted in massive provision of poor quality education, which is the third factor. This contradiction raises the debate about the appropriateness of TVET in SSA as the country aims to industrialise and therefore requires a skilled workforce to meet this objective.

\subsection{Evolution of Education in the Different Phases of Development in SSA}

Africa is, of course, a very heterogeneous continent, composed of countries that vary greatly in terms of geographical size and population, and whose income varies from low to medium. Despite many differences across the continent, African countries do have some similarities, particularly in terms of their industrialisation trajectory and also in terms of education. Indeed, there are deeply rooted cultural preferences for general education, which originated in the type of education systems in place. The evolution of education in SSA can be divided into three phases that have marked the development history of African countries since independence. These are phases of evolution of education are: post-independence period, the period of structural adjustment programmes and the recovery period of the 2000s.

In the first instance, after independence, many African governments significantly expanded education, including building national universities, while trying to industrialise through state-owned enterprises and import substitution industrialisation (CNUCED, 2011; Newman, 2016). Ghana after independence in 1957 adopted a policy of import substitution industrialisation. Other countries followed similar industrialisation strategies. These countries included Senegal in the late 1960s, Kenya and Tanzania, which emphasised socialism and self-reliance. In Ethiopia, the government nationalised most medium and large private enterprises. From 1975 onwards, the Mozambican government introduced a set of policies aimed at making the public sector the main source of revenue. To support their industrialisation, governments, in some cases, attempted to train their population to tilt towards vocational education (Foster, 1965; McGrath et al., 2020; Oketch, 2014). However, government and state-owned enterprises, the main employers at the time, hired mainly general education graduates, reinforcing preferences for general education and the association of vocational education with educational failure. The limited industrial trajectory did not lead to substantial economic development or a substantial expansion of the labour market in terms of the number of middle-level jobs.

In the second phase, the structural adjustment period halted the industrialisation trajectory as well as the expansion of education and other social services, leading to over a decade of very poor development outcomes. One of the 
explicit objectives of structural adjustment programmes was to reduce the role of the state in the industrialisation and development process (CNUCED, 2011). However, competition from imports, lack of technical expertise and shortage of working capital meant that most state-owned enterprises operated at only 10 per cent of their capacity (Newman, 2016).

In the third phase, the region began to experience positive per capita income growth around 1995, a trend that accelerated during the 2000s. Improved economic performance led to the withdrawal of structural adjustment loans, and the Millennium Development Goals (MDGs) established a new aid agenda for the region. The MDGs set a new aid agenda for Africa, with a primary focus on human development (Arndt et al., 2016). However, this growth has not always been associated with improvements in people's well-being or increases in productivity. In 2016, point out that Ethiopia, Ghana, Kenya, Nigeria, Senegal, Tanzania, Mozambique and Uganda contribute 54\% of the region's GDP and with a combined manufacturing sector that makes up the largest share of the region's GDP, their combined manufacturing sector accounted for about one-fifth of sub-Saharan Africa's manufacturing value added (excluding South Africa). However, they go on to say that while these eight countries are emerging markets in Africa, they are not emerging industrial economies (Newman, 2016).

\section{Recent Performance of Manufacturing and TVET in SSA}

\subsection{Sectoral Value Added (\% GDP)}

The evolution of economic structure of SSA countries over the last decades shows that in terms of sectoral composition, the industrial sector has performed poorly. The following figure shows the evolution of 5-year average real value added (\% of GDP) of the different sectors in SSA. Indeed, Figure 1 shows that the services sector remains the dominant sector in SSA economies. More importantly, it shows an upward trend in the real value added of services in SSA since 1995 after a relative constancy before that date. This increase could be explained by the adoption and implementation of new technologies that improved the quality of services available in a predominantly informal sector. In contrast, the region has experienced a downward trend in value added in agriculture and industry over the entire period. As (Rodrik, 2015) points out, this was a deindustrialisation of SSA.

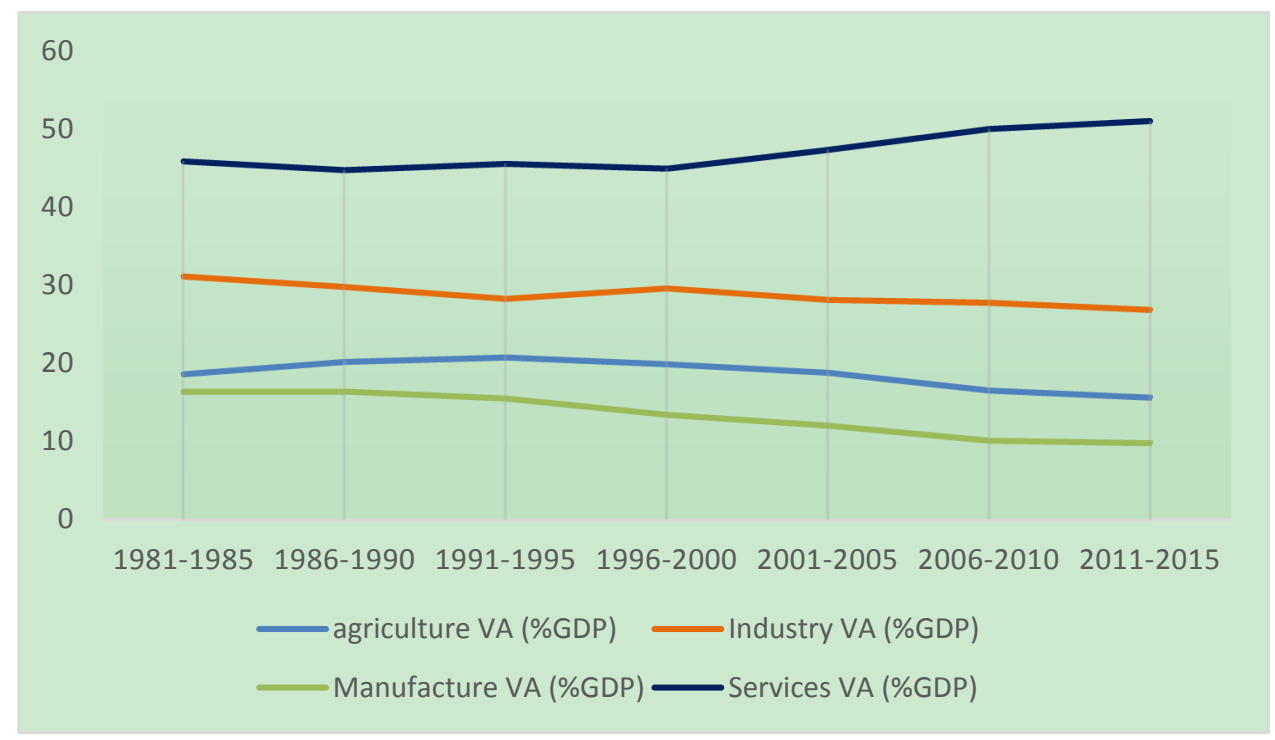

Figure 1. Evolution of value added (\%GDP) in the different sectors in SSA

Source: Author, based on WDI data (year).

The industrial sector includes the manufacturing and non-manufacturing sectors. The non-manufacturing sector consists mainly of the extractive industry. Studies tend to show that manufacturing was the industry that offerred the most opportunities for sustainable growth, employment and poverty reduction in Africa (Volger, 2010). The manufacturing value added curve is lower than that of industry, services and even agriculture. This shows that industrialisation in SSA is driven by the non-manufacturing sector characterised by extractive activities and the exploitation of natural resources, which gave these countries a weak industrial base.

The evolution of growth rates in GDP per capita, manufacturing and industrial value added shows that industrialisation in SSA seems to have evolved in parallel with the living standards of the population (Figure 2). 
The continent has performed well economically in recent years. It has experienced a growth rate hovering around 5\% since the 2000s, with leading countries such as Angola and Ethiopia second only to the East and South Asian region (UNECA, 2016). Nevertheless, it turns out that SSA remains the poorest region in the world, this growth is not inclusive, it is locked in a vicious circle of poverty (Myrdal \& Sitohang, 1957): low income leads to low savings which leads to low investment with consequent low output and national income. Market forces alone would then keep Third World economists in underdevelopment. External intervention (public savings, development aid, external borrowing, foreign direct investment) is needed to break this vicious circle, and to create the conditions for a virtuous circle. This is why it is necessary to transform the productive structure of SSA countries.

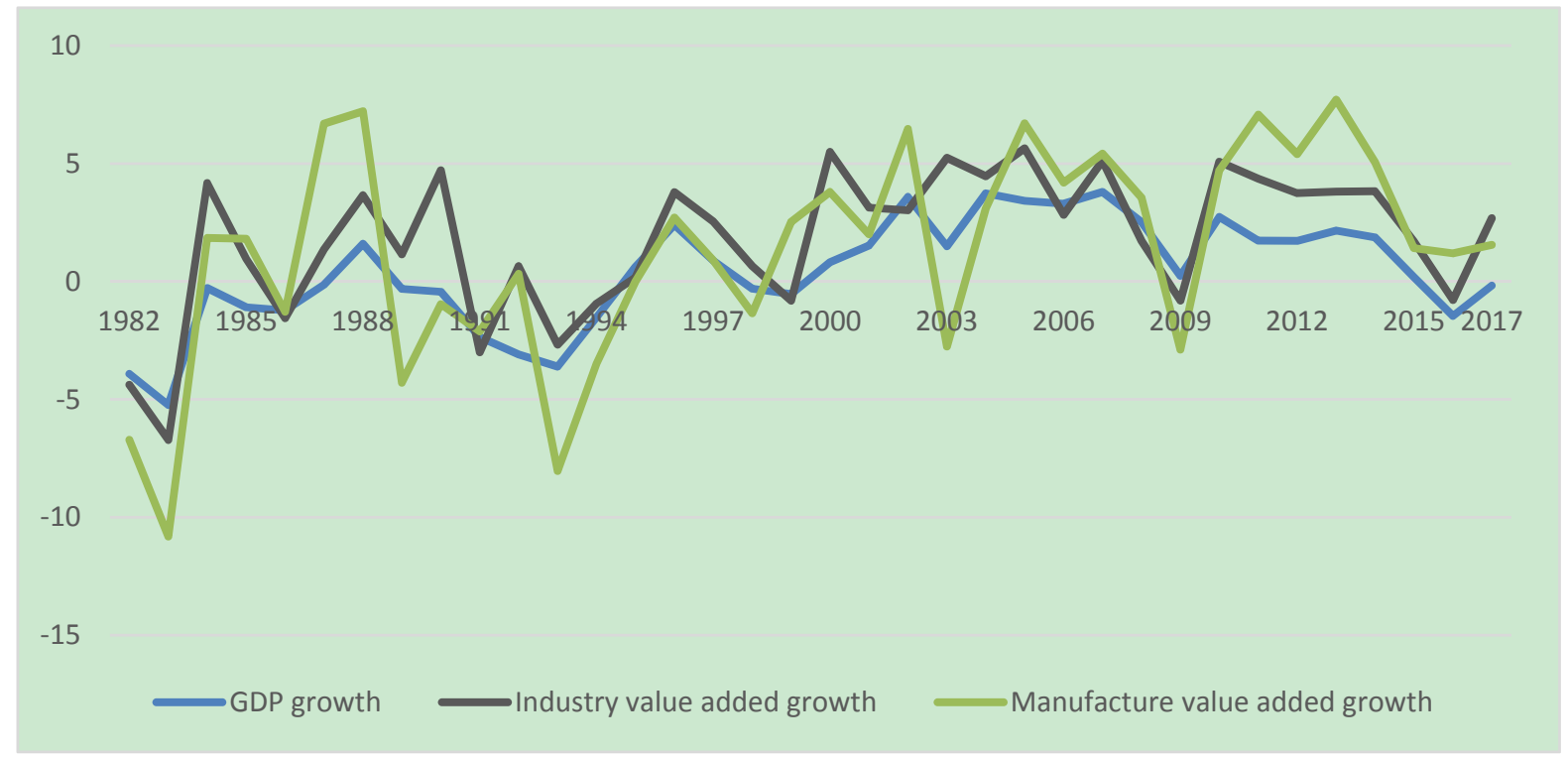

Figure 2. Annual growth of GDP/head, industrial and manufacturing value added in SSA

Source: Author, based on WDI data(year).

\subsection{The Share of Agricultural Employment in SSA}

Figure 3 shows the trend in the five-year average share of employment in total employment for each sector. The average contribution of employment in agriculture for SSA decreased from $68 \%$ in 1990 to $58 \%$ in 2015 . Indeed, as the figure below shows, the share of agricultural employment has been declining steadily since 1990. However, the agricultural sector still employs a large share of the working population in SSA. This explains the increased weakness in relative labour productivity.

On the other hand, the share of employment in services is constantly increasing. It rose averagely from $25 \%$ between 1991-1995 to 30\% between 2011-2015. Employment in the industrial sector has not varied significantly around its average of $10 \%$ over 1991-2015 period. This also firmly laid credence to the problem of deindustrialisation in SSA. The causes of this deindustrialisation were multiple factors such as lack of energy, transport and telecommunication infrastructure (Rodrik, 2015); low levels of human capital ; agricultural policies ill-suited to a growing industry (Page, 2012); low productive diversification, problems of corruption and dysfunctional credit markets (Boillot, Lemoine, 1992). 


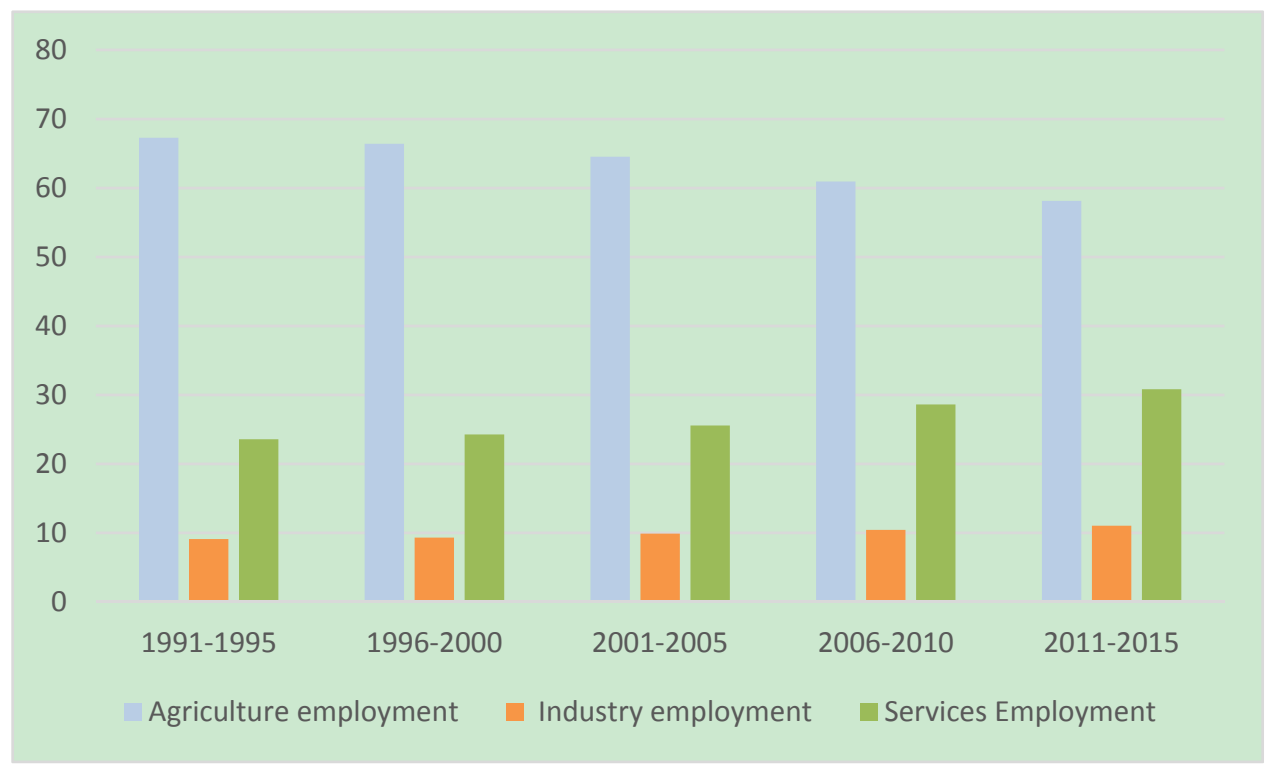

Figure 3. Evolution of the 5-year average of sectoral employment in SSA

Source: Author, based on WDI data.

\subsection{Educational Developments}

The structure of the proportion of students enrolled in secondary education has not really changed over the years. Indeed, the proportion of students enrolled in general secondary education has been around $90 \%$, while the proportion of students enrolled in technical secondary education has been around $10 \%$ since the 1970 s. This shows the huge gap between the two subsystems. Indeed, TVET is most often seen as a school for those left behind in general education. However, SSA has set itself industrialisation targets which require a skilled workforce capable of meeting these needs. The ability of TVET to meet these needs has been demonstrated in several countries that are now industrialised, and TVET is thus a means to achieving industrialisation (CEA, 2020).

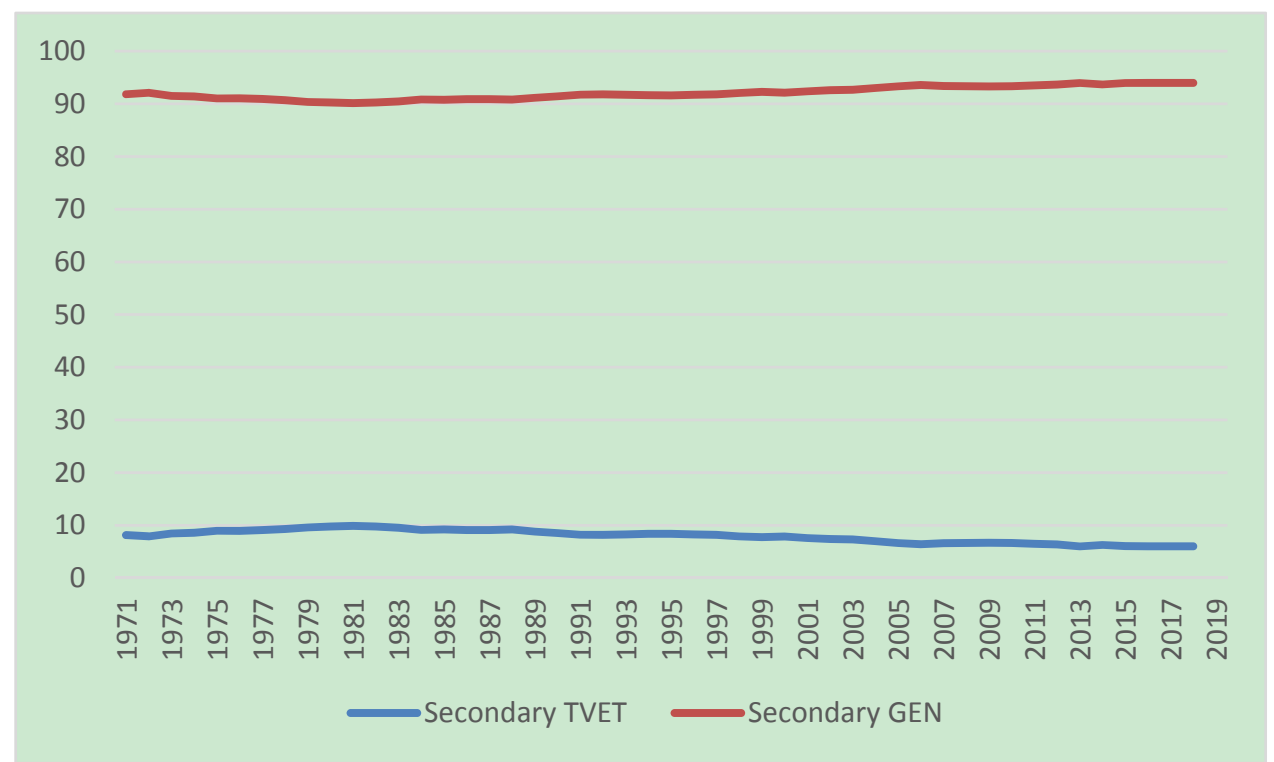

Figure 4. Evolution of the proportions of students in technical and general secondary education in SSA Source: Author, based on UNESCO data.

\subsection{Education and Industrialisation}

The Figure 5 shows the analyses of the correlation between TVET and industrial value added (IVA) (a), and 
between general education (EGEN) and IVA (b). The relationship between TVET and IVA is positive and increasing, with some countries such as Gabon, Angola and Congo standing out with an average level of TVET and a high level of IVA. On the other hand, the relationship between EGEN and industrial value added is negative and decreasing. Indeed, countries with a high level of EGEN such as Chad, Ethiopia or Gambia have a relatively low IVA.
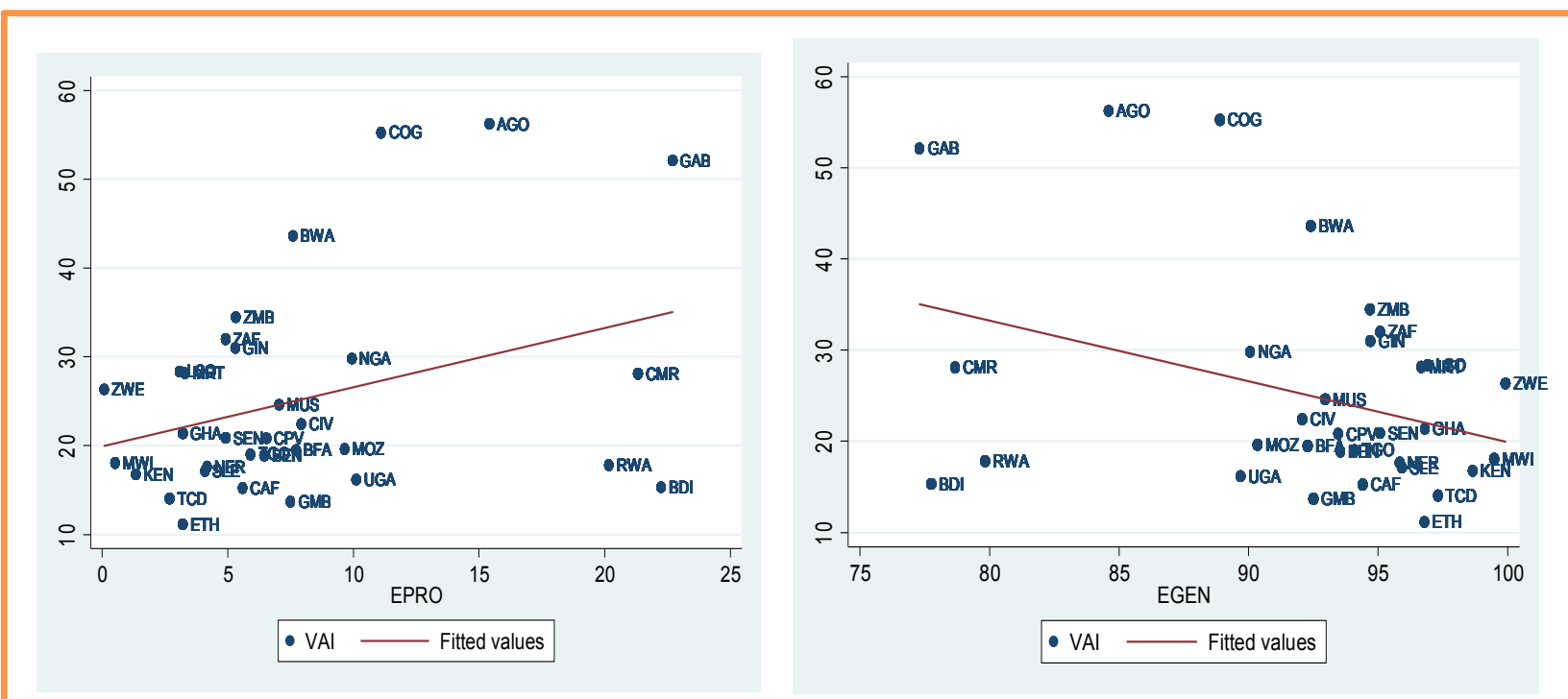

(a)

Figure 5. Education and industrialisation in SSA

Source: Author, based on UNESCO data.

\section{Econometric Modelling of the Link between Industrialisation and TVET}

In this section, we present in turn the databases used, the different variables used in our specification, the model used and the results obtained.

\subsection{The Data Used}

Our analysis of the effect of TVET on industrialisation in SSA is based on a combination of data on the main macroeconomic indicators of 32 SSA countries over the period 1980-2018. The choice of these economies for this study is motivated by the availability of relevant data on industrialisation as well as on our different key variables. For this purpose, we used data from WDI (World Development Indicator, 2020), ILO (International Labour Organisation, 2019), Fraser Institute (2020) and UNESCO (2019) as the main databases.

\subsection{The Variables}

We distinguish between variables of interest and control variables.

\subsubsection{Variables of Interest}

The objective of our analysis is to assess the effect of education on the industrialisation process in SSA. Three indicators can be used to measure industrialisation according to Chandra (2003), Echaudemaison (2003) and (Volger, 2010), namely, manufacturing and industrial value added as a percentage of GDP (constant prices), which captures the ability to transform natural resources into final goods (Dodzin and Vamvakidis, 2004; Ongo, 2016). Next, we have the share of manufacturing employment in total employment, which explains how intermediate goods are transformed and describes the quality of the labour required (Gui-Diby \& Renard, 2015; Kang \& Lee, 2011). In addition, we focus primarily on TVET in secondary education for several reasons. High levels of TVET in secondary education have played a central role in 20th century development in Europe and East Asia, and represent an important public investment in skills. Moreover, TVET in secondary education is easier to measure internationally than other dimensions of skills regimes. Finally, data on TVET is not widely available at tertiary level and over a long period of time for SSA countries. 


\subsubsection{Control Variables}

This section presents the internal and external factors to industrialisation and the theories underlying these different variables. Indeed, the level of household income (GDP per capita is used as an indicator) is an essential element in the theory of push industrialisation (Murphy et al., 1989). Differences in income may be important since countries that start from a lower level of economic development are more likely to catch up with more advanced countries and thus undertake sustainable industrialisation patterns. Indeed, poorer countries are characterised by a higher rate of productivity growth in their manufacturing sector, which favours an unconditional convergence with the technological frontier (Rodrik, 2013). International trade can also be an explanatory factor for industrialisation: according to (Ramaswany \& Rowthorn, 1997), the trade surplus in manufactured goods is positively correlated with domestic manufacturing output and employment and can help finance a trade deficit in non-manufactured goods. Furthermore, they find that imports have a negative impact on industrialisation, and Kaya (2010) finds that the impact of low-tech exports on industrialisation is positive.

Also, FDI variable is the total net inflow of foreign direct investment as a percentage of GDP (both variables are in current prices) as suggested in (Kang \& Lee, 2011) and (Kaya, 2010). This variable has some limitations as it incorporates manufacturing and natural resource FDI flows, whereas this study focuses on the manufacturing sector. Unfortunately, data presenting the sectoral breakdown of FDI flows received by African countries are not always available and cannot be a robust analysis. Furthermore, the literature highlights the role of the public sector in the industrialisation processes of many countries. Stable and dynamic institutions have been identified as key factors in the process of industrialisation. The government's interventions in this study are represented by Economic Freedom Index (EFI) produced by the Fraser Institute. Ethnic fragmentation is also a determinant of industrialisation. Indeed, a large body of literature argues that a low-fragmented society is likely to induce the development of social networks, promote civic engagement and contribute to industrialisation (Leonardi et al., 2001).

\subsection{Methodology}

The basic model is presented as follows:

$$
I N D U_{i t}=\alpha X_{i t}+\beta E D U C_{i t}+\varepsilon_{i t}+\text { region }
$$

Where EDUC is either TVET or EGEN, the matrix $X_{i t}$ consists of the following variables: GDP, TRADE, FDI, Ethnicfrac and EFI. The INDU variable represents the level of industrialisation, $\varepsilon_{i t}$ represents the residual, and region (central, east, north, south and west Africa) represents the region dummies as the levels of development may be different.

i. Taking into account the three measures of industrialisation, the estimated models are as follows: When industrialisation is measured by manufacturing value added, the we have:

$$
\text { Indus_VAM }{ }_{i t}=\alpha+\beta_{1} E d u c_{i t}+\beta_{2} G D P_{i t}+\beta_{3} T R A D E_{i t}+\beta_{4} E_{\text {thnicfract }}+\beta_{5} F D I_{i t}+\beta_{6} E F I_{i t}+\varepsilon_{i t}
$$

ii. When industrialisation is measured by industrial value added:

$$
\text { Indus_VAI } I_{i t}=\alpha+\beta_{1} E d u c_{i t}+\beta_{2} G D P_{i t}+\beta_{3} T R A D E_{i t}+\beta_{4} E_{t h n i c f r a c t}+\beta_{5} F D I_{i t}+\beta_{6} E F I_{i t}+\varepsilon_{i t}
$$

iii. When industrialisation is measured by the share of manufacturing employment in total employment:

$$
\text { Indus_Emploi } i_{i t}=\alpha+\beta_{1} E d u c_{i t}+\beta_{2} G D P_{i t}+\beta_{3} T R A D E_{i t}+\beta_{4} \text { Ethnicfract }_{i t}+\beta_{5} F D I_{i t}+\beta_{6} E F I_{i t}+\varepsilon_{i t}
$$

\subsection{Descriptive Statistics}

The following table presents the descriptive statistics of the different variables of the model. These statistics show that the most dispersed variables are income and trade openness (Table 1). 
Table 1. Descriptive statistics of variables

\begin{tabular}{llllll}
\hline Variables & Observations & Mean & Standard deviations & Min & Max \\
\hline VAM & 840 & 10.0604 & 5.0067 & 0.2326 & 33.3459 \\
\hline TVET & 504 & 6.2889 & 6.6025 & 0.0000 & 45.2286 \\
EGEN & 504 & 93.7021 & 6.6008 & 54.7714 & 100.0000 \\
GDP & 896 & 1775.8940 & 2335.2760 & 164.3366 & 11937.6400 \\
FDI & 891 & 3.4939 & 6.0765 & -8.5894 & 50.63641 \\
TRADE & 835 & 68.3355 & 28.7049 & 20.7225 & 165.6459 \\
EFI & 570 & 6.0306 & 0.8699 & 2.8000 & 8.2100 \\
Ethnicfract & 896 & 2.2135 & 6.1945 & 0.2550 & 38.4174 \\
\hline
\end{tabular}

Source: Author's own computation

\subsection{Correlation Analysis}

The following table shows the correlation between the variables in the model. Thus, the correlation matrix shows that, the correlation between industrialisation and income and between industrialisation and EFI is positive but modest, TVET and industrialisation are positively correlated, while general education, FDI, trade openness and ethnic fragmentation are negatively correlated with industrialisation (Table 2).

Table 2. Correlation matrix of variables

\begin{tabular}{lllllllll}
\hline & VAM & EPRO & EGEN & GDP & FDI & Trade & Ethnicfract & EFI \\
\hline VAM & 1.0000 & & & & & & & \\
TVET & 0.0448 & 1.0000 & & & & & & \\
EGEN & -0.0438 & -0.9996 & 1.0000 & & & & & \\
GDP & 0.1693 & 0.1797 & -0.1788 & 1.0000 & & & & \\
FDI & -0.1409 & -0.1795 & 0.1789 & -0.1346 & 1.0000 & & & \\
Trade & -0.0124 & -0.0200 & 0.0214 & 0.3507 & 0.3168 & 1.0000 & & \\
Ethnicfract & -0.2559 & 0.1979 & -0.1974 & -0.0403 & -0.0012 & -0.0694 & 1.0000 & \\
EFI & 0.1384 & 0.0301 & -0.0326 & 0.5642 & -0.0048 & 0.2041 & 0.3046 & 1.0000 \\
\hline Source: Auth
\end{tabular}

Source: Author's own computation

\subsection{The Empirircal Model Used}

The two-stage least squares estimation technique is well suited to the analysis of structural equations that suffer from the endogeneity problem, resulting from reverse causality between dependent and independent variables, and/or omitted variable bias, and/or measurement errors. It is essentially an alternative to the OLS estimation technique which, in the case of endogeneity problems, produces biased estimates. The endogeneity problem in panel data is likely to be detected from statistical evidence of correlation between the error term and the explanatory variable(s). In such circumstances, the assumption of OLS estimation that the error terms are independent of the regressor(s) is violated. The effectiveness of the OLS estimator in generating unbiased estimates is thus marginalized. Thus, the IV-2SLS estimation technique addresses this problem by incorporating instruments into the econometric model(s) (Benda \& Corwyn, 1997). The choice of instruments is crucial in determining the outcome of the regression estimates. Instruments are used to modify the endogenous regressor(s) that is correlated with the error term. A credible instrumental variable must be an exogenous variable that can directly affect the endogenous variable while indirectly influencing the outcome variable in the regression model.

The two-stage least squares estimation process essentially consists of two steps. In the first step, instruments are used to transform the endogenous regressor(s), trade openness in the context of this paper, in order to estimate its predicted value. All four regression models considered in this paper can be combined and written as follows: 


$$
\mathrm{Y}_{\mathrm{k}, \mathrm{it}}=\beta_{1}+\beta_{2} T V E T_{i t}+\varepsilon_{i t}
$$

Where $\mathrm{Y}$ is the industrialisation $(\mathrm{k}=1, \ldots, 3)$ in three basic regression models. TVET is designated as the endogenous regressor of industrialisation, following its correlation with the error term $(\varepsilon)$. In order to instrument TVET, its first, second and third order lags are used as potential instruments. The three instruments must comply with the preconditions for their inclusion in the models, namely that these variables must be correlated with the endogenous variables [i.e. corr corr (TVET, TVET $T_{t-1}$ ), corr (TVET, TVET $T_{t-2}$ ) and corr (TVET, TVET $T_{t-3}$ ) are not equal to zero] and also be independent of the error term [i.e. $\left.\operatorname{corr}\left(T V E T_{t-1}, \varepsilon\right)=\operatorname{corr}\left(T V E T_{t-2}, \varepsilon\right)=\operatorname{corr}\left(T V E T_{t-3}, \varepsilon\right)=0\right]$. In the first step, TVET is regressed on the instrumental variables and the other regressors to estimate the predicted value $\mathrm{P}(\mathrm{TVET})$ and the corresponding regression result can be given as follows:

$$
P(\text { TVET })_{i t}=\rho_{1}+\rho_{2} \text { TVET }_{i t-1}+\rho_{3} T_{V E T} T_{i t-2}+\rho_{4} T V E T_{i t-3}+\beta_{j} X_{j, i t}+\varepsilon_{i t}
$$

In the second step, the endogenous variable is replaced by its predicted value, obtained in the first step, in the equation preceding the first step and is regressed using the OLS estimator. The second stage regression model can be written as follows:

$$
Y_{k, i t}=\delta_{1}+\delta_{2} P(T V E T)_{i t}+\beta_{j} X_{j, i t}+\varepsilon_{i t}
$$

The estimated coefficients of the second stage are assumed to be unbiased, provided that the appropriate instrument qualities are ensured.

\section{The Discussion of the Estimated Model Results}

The following table presents the results obtained from a two-stage least squares estimation. Columns (1) and (3) (respectively (2) and (4)) present the results when considering TVET (respectively general education) as the variable of interest and the control variables, when industrialisation is captured by manufacturing value added and industrial value added respectively. GDP per capita had a positive and significant impact on the industrialisation process in sub-Saharan Africa. This result is consistent with (Totouom et al., 2019). This can be explained by the fact that poorer countries are characterised by a higher rate of productivity growth in their manufacturing sector, which favours unconditional convergence with the technological frontier and thus industrialisation.

FDI had a positive and significant effect on industrialisation (Table 3). This effect becomes negative when industrialisation is captured by the share of manufacturing employment in total employment. The positive effect for the first two measures of industrialisation is consistent with the result obtained by Ongo Nkoa (2016) who argues that SSA has turned to a structural transformation of its economy. This policy has led to a diversification of development partners, indispensable for the industrialisation needs.

Trade openness is positive and significant at $1 \%$ on industrialisation when captured by industrial value added, it is insignificant for manufacturing value added. This result is contrary to that found by Ongo Nkoa (2016) who believes that trade liberalisation policies advocated by the World Trade Organisation (WTO) have weakened local industry. The entry of diversified and high value-added products competes with local products thus reducing local production. 
Table 3. Effect of TVET on industrialisation in SSA 2SLS

\begin{tabular}{|c|c|c|c|c|}
\hline & (1) & (2) & (3) & (4) \\
\hline VARIABLES & Indus_VAM & Indus_VAM & Indus_VAI & Indus_VAI \\
\hline \multirow[t]{2}{*}{ EGEN } & & $-2.723 * * *$ & & $-2.043 * * *$ \\
\hline & & $(0.991)$ & & $(0.243)$ \\
\hline \multirow[t]{2}{*}{ TVET } & $0.211 * * *$ & & $0.0958 * * *$ & \\
\hline & $(0.0635)$ & & $(0.0311)$ & \\
\hline \multirow[t]{2}{*}{$\operatorname{lnGDP}$} & $0.145^{* *}$ & $0.146^{* * *}$ & $0.104 * * *$ & $0.0883 * * *$ \\
\hline & $(0.0711)$ & $(0.0526)$ & $(0.0337)$ & $(0.0285)$ \\
\hline \multirow[t]{2}{*}{ FDI } & $0.236^{*}$ & $0.267 *$ & 0.0853 & $0.117 * *$ \\
\hline & $(0.139)$ & $(0.138)$ & $(0.0651)$ & $(0.0519)$ \\
\hline \multirow[t]{2}{*}{ TRADE } & -0.143 & -0.161 & $0.225 * * *$ & $0.230 * * *$ \\
\hline & $(0.153)$ & $(0.143)$ & $(0.0641)$ & $(0.0466)$ \\
\hline \multirow[t]{2}{*}{ Ethnicfract } & $-0.152 * * *$ & $-0.165 * * *$ & $-0.0574 * * *$ & $-0.0697 * * *$ \\
\hline & $(0.0202)$ & $(0.0219)$ & $(0.0113)$ & $(0.00918)$ \\
\hline \multirow[t]{2}{*}{ EFI } & 0.0268 & -0.0102 & -0.0387 & -0.0416 \\
\hline & $(0.110)$ & $(0.0599)$ & $(0.0499)$ & $(0.0415)$ \\
\hline \multirow{2}{*}{$\begin{array}{l}\text { 2.REGION } \\
(\mathrm{EAST})\end{array}$} & $0.798 * * *$ & $1.038 * * *$ & -0.0180 & 0.0818 \\
\hline & $(0.230)$ & $(0.201)$ & $(0.0898)$ & $(0.0786)$ \\
\hline \multirow{2}{*}{$\begin{array}{l}\text { 3.REGION } \\
\text { (WEST) }\end{array}$} & $0.691 * * *$ & $0.914 * * *$ & $0.394 * * *$ & $0.542 * * *$ \\
\hline & $(0.229)$ & $(0.236)$ & $(0.0860)$ & $(0.0771)$ \\
\hline 4.REGION & $0.670 * * *$ & $0.833 * * *$ & $0.183 * *$ & $0.295 * * *$ \\
\hline (SOUTH) & $(0.196)$ & $(0.203)$ & $(0.0832)$ & $(0.0785)$ \\
\hline \multirow[t]{2}{*}{ Constant } & -0.00583 & $12.77 * * *$ & $1.083 * * *$ & $10.44 * * *$ \\
\hline & $(0.470)$ & $(4.484)$ & $(0.227)$ & $(1.102)$ \\
\hline $\begin{array}{l}\text { Time fixed } \\
\text { Effects }\end{array}$ & YES & YES & YES & YES \\
\hline Observations & 189 & 207 & 191 & 207 \\
\hline \multicolumn{5}{|l|}{ R-squared } \\
\hline Hansen $J$ test (p- & 0.557 & 0.458 & 0.566 & 0.652 \\
\hline value) & 0.8510 & 0.1568 & 0.1581 & 0.3434 \\
\hline $\begin{array}{l}\text { Under id. test (p- } \\
\text { value) }\end{array}$ & 0.000 & 0.000 & 0.000 & 0.000 \\
\hline
\end{tabular}

Standard deviations are in brackets

$* * * \mathrm{p}<0.01,{ }^{* *} \mathrm{p}<0.05,{ }^{*} \mathrm{p}<0.1$

Source: Author's owm estimation

Again, Ethnic fragmentation had a negative effect on industrialisation. We introduced an ethnic fractionation index (Ethnicfract) to account for social stability. A large body of literature argues that less fragmentation and the development of social networks can promote civic engagement and contribute to industrialisation (Leonardi et al., 2001). On the other hand, a more fragmented society is expected to be less cohesive and therefore less able to join forces, and also contributes less to the development of local industries. Indeed, our results seem to confirm these 
arguments, showing that a more cohesive society was on average more likely to undertake prolonged phases of strong industrialisation. The institutional variable represented by the EFI is not significant.

The analysis of the effect of TVET on industrialisation at the sub-regional level (region) shows that, TVET contributed to manufacturing value added in all SSA sub-regions. This interesting result supports that in East Africa, a one percent increase in TVET increases manufacturing value added by $0.798 \%$. It is $0.691 \%$ and $0.670 \%$ in West Africa and Southern Africa respectively. General education had also a negative and significant $1 \%$ effect on industrialisation. Thus, general education reduces industrialisation in SSA by $-2.723 \%$. This can be explained by the fact that in Africa in general, individuals undertake general education with the aim of finding a job in the civil service. Because the civil service is a guarantee of stability. However, this sector is not in essence a production sector and therefore does not drive industrialisation (Gurgand, 1993). As for TVET, it had a positive and significant effect at $1 \%$ on industrialisation. TVET contributes $0.211 \%$ to manufacturing value added, $0.0958 \%$ to industrial value added and $0.0179 \%$ to manufacturing employment. This result can be explained by the fact that TVET provides adequate labour for the industrialisation needs of SSA countries.

\subsection{General Discussion}

In order to improve productivity, boost competitiveness and ensure sustainable economic development, skills development is vital. TVET plays an important role in providing the skills, knowledge, attitude and values necessary for development and has emerged as one of the most effective human resource development strategies needed by African countries to train and upgrade their technical workforce for rapid industrialisation and national development. Therefore, vocational training is important for sustainable industrialisation and poverty reduction in terms of creating a critical mass of technically and entrepreneurially skilled people who can stimulate investment opportunities, create jobs and increase competitive productivity, which can be provided by a well-trained workforce. TVET ensures this through its practical application, as opposed to theory, and through the acquisition of skills. TVET therefore prepares learners for careers based on manual and practical activities. It is a training opportunity in which the learner directly participates and develops specific skills and expertise. However, given the many developmental challenges facing sub-Saharan Africa, TVET is not only important, but a prerequisite for mitigating these challenges. This result is similar to that of (Mupimpila \& Narayana, 2009) who find that the impact of vocational training on economic growth in Botswana was greater than that of higher education.

\subsection{Robustness}

We check the sensitivity of the results using an alternative measure of industrialisation. For this purpose, we captured industrialisation by the share of manufacturing employment in total employment, which explains how intermediate goods are processed and describes the quality of the labour required. The sensitivity analysis seems to show that apart from FDI and EFI, the other variables seem to retain the same sign, and to some extent the same degree of significance. Indeed, FDI had a negative effect when industrialisation is captured by the share of manufacturing employment in total employment. As found by (Gui-Diby \& Renard, 2015), the negative effect can be explained by two reasons: the inefficiency of government interventions and the weak capacity of governments to create an enabling environment to attract FDI flows into manufacturing. EFI has a positive and significant effect at the $5 \%$ level on industrialisation. Indeed, the stronger the institutions in a country, the better the governance and the higher the level of industrialisation. Thus, TVET positively affects industrialisation in all its dimensions. 
Table 4. Effect of education on industrialisation; INDUSemp = share of manufacturing employment in total employment

\begin{tabular}{|c|c|c|}
\hline & (1) & (2) \\
\hline VARIABLES & INDUSemp & INDUSemp \\
\hline \multirow[t]{2}{*}{ EGEN } & & -0.101 \\
\hline & & $(0.0889)$ \\
\hline \multirow[t]{2}{*}{ TVET } & $0.0179 * * *$ & \\
\hline & $(0.00360)$ & \\
\hline \multirow[t]{2}{*}{ LnGDP } & $0.0156 * * *$ & $0.0155 * * *$ \\
\hline & $(0.00551)$ & $(0.00395)$ \\
\hline \multirow[t]{2}{*}{ FDI } & $-0.0359 * * *$ & $-0.0323 * * *$ \\
\hline & $(0.00826)$ & $(0.00787)$ \\
\hline \multirow[t]{2}{*}{ TRADE } & $0.0485 * * *$ & $0.0377 * * *$ \\
\hline & $(0.0104)$ & $(0.0112)$ \\
\hline \multirow[t]{2}{*}{ Ethnicfract } & $-0.0141 * * *$ & $-0.0145^{* * *}$ \\
\hline & $(0.00150)$ & $(0.00156)$ \\
\hline \multirow[t]{2}{*}{ EFI } & 0.0104 & $0.0107 * *$ \\
\hline & $(0.00906)$ & $(0.00522)$ \\
\hline \multirow[t]{2}{*}{ 2.REGION } & $0.0268 * *$ & $0.0455 * * *$ \\
\hline & $(0.0135)$ & $(0.00879)$ \\
\hline \multirow[t]{2}{*}{ 3.REGION } & $0.0416 * * *$ & $0.0526 * * *$ \\
\hline & $(0.0122)$ & $(0.0110)$ \\
\hline \multirow[t]{2}{*}{ 4.REGION } & $0.0707 * * *$ & $0.0730 * * *$ \\
\hline & $(0.00793)$ & $(0.00791)$ \\
\hline \multirow[t]{2}{*}{ Constant } & $-0.271 * * *$ & 0.242 \\
\hline & $(0.0369)$ & $(0.402)$ \\
\hline Time fixed Effects & YES & YES \\
\hline Observations & 198 & 216 \\
\hline R-squared & 0.680 & 0.594 \\
\hline Hansen J test (p-value) & 0.6618 & 0.7969 \\
\hline Under id. test (p-value) & 0.000 & 0.000 \\
\hline
\end{tabular}

Standard deviations are in brackets

$* * * \mathrm{p}<0.01,{ }^{* *} \mathrm{p}<0.05,{ }^{*} \mathrm{p}<0.1$

Source: Author's owm estimation

\section{Conclusion}

In this study, we investigated whether TVET is a key determinant of industrialisation in SSA. We considered the period from 1980 to 2018 for 32 SSA countries. Using the double least squares method, we found that TVET has a positive and significant effect at the $1 \%$ level on industrialisation and this result is consistent with the three different measures of industrialisation used in this study. General education, on the other hand, has a negative effect on industrialisation. To achieve its industrialisation goals and have the necessary workforce to do so, we recommend that pedagogy and teacher training for TVET must be improved to provide the quality TVET needed to properly prepare young people for the entrepreneurial education experience. In addition to this, the government should accelerate the establishment of entrepreneurship development centres in all secondary education institutions in the countries, which can be done by providing a special intervention for this purpose. 


\section{References}

Acemoglu, D., \& Guerrieri, V. (2008). Capital Deepening and Nonbalanced Economic Growth. Journal of Political Economy, 116(3), 467-498. https://doi.org/10.1086/589523

African Development Bank. (2017). Industrialize Africa : Strategies, Policies, Institutions, and Financing. African Development Bank Group.

Allais, S. (2020). Skills for industrialisation in sub-Saharan African countries : Why is systemic reform of technical and vocational systems so persistently unsuccessful? Journal of Vocational Education \& Training, 1-19. https://doi.org/10.1080/13636820.2020.1782455

Arndt, C., McKay, A., \& Tarp, F. (Éds.). (2016). Growth and Poverty in Sub-Saharan Africa. Oxford University Press. https://doi.org/10.1093/acprof:oso/9780198744795.001.0001

Backes-Gellner, U., \& Lehnert, P. (2021). The Contribution of Vocational Education and Training to Innovation and Growth. In Oxford Research Encyclopedia of Economics and Finance. doi.org/10.1093/acrefore/9780190625979.013.653

Baumol, W. (1967). Macroeconomics of unbalanced growth: The anatomy of urban crisis. The American Economic Review, 57(3), 415-426.

Becker, G. S. (1964). Human Capital : A Theoretical and Empirical Analysis, with Special Reference to Education. National Bureau of Economic Research.

Benda, B. B., \& Corwyn, R. F. (1997). A test of a model with reciprocal effects between religiosity and various forms of delinquency using 2-stage least squares regression. Journal of social service research, 22(3), 27-52.

CEA. (2020). Bâtir les compétences pour la diversification économique en Afrique centrale, Rapport thématique.

Chandra, R. (2003). Industrialization and development in the Third World. Routledge.

Chen, C. (2020). Capital-skill complementarity, sectoral labor productivity, and structural transformation. Journal of Economic Dynamics and Control, 116, 103902. https://doi.org/10.1016/j.jedc.2020.103902

Chenery, H. B., Robinson, S., Syrquin, M., \& Feder, S. (1986). Industrialization and growth. Citeseer.

CNUCED. (2011). Economic Development in Africa Report 2011 : Fostering Industrial Development in Africa in the New Global Environment. New York and Geneva: United Nations.

CNUCED. (2016). La transformation structurelle au service d'une croissance équitable et soutenue. Nations Unis, New York Genève.

Echaudemaison, C. (2003). Dictionnaire d'économie et de sciences sociales (6 éd.). Paris: Nathan.

Fluitman, F. (1992). Traditional Apprenticeship in West Africa : Recent Evidence and Policy Options. Discussion Paper No. 34. ERIC.

Foster, P. J. (1965). The vocational school fallacy in development planning. Education and economic development, $32,142-166$.

Grootaert, C. (1990). Returns to formal and informal vocational education in Cote d'Ivoire: The role of the structure of the labor market. Economics of Education Review, 9(4), 309-319.

Gui-Diby, S. L., \& Renard, M.-F. (2015). Foreign Direct Investment Inflows and the Industrialization of African Countries. World Development, 74, 43-57. https://doi.org/10.1016/j.worlddev.2015.04.005

Gurgand, M. (1993). Les effets de l'éducation sur la production agricole. Application à la Côte-d'Ivoire. Revue d'économie du développement, 1(4), 37-54.

Han, J.-H. (1994). Education and Industrialization: The Korean Nexus in Human Resources Development. Education Economics, 2(2), 169-185. https://doi.org/10.1080/09645299400000015

Hanushek, E. A., Schwerdt, G., Woessmann, L., \& Zhang, L. (2017). General education, vocational education, and labor-market outcomes over the lifecycle. Journal of human resources, 52(1), 48-87.

Hinchliffe, K. (1990). The returns to vocational training in Botswana-Research note. Economics of education review, 9(4), 401-404.

Hirschman, A. O. (1958). The strategy of economic development. Boulder and London. Westview Press [first publ. 1958]. 
Kahyarara, G., \& Teal, F. (2008). The Returns to Vocational Training and Academic Education : Evidence from Tanzania. World Development, 36(11), 2223-2242. https://doi.org/10.1016/j.worlddev.2007.11.011

Kaldor, N. (1967). Strategic factors in economic development.

Kanbur, R. (2017). Structural transformation and income distribution: Kuznets and beyond.

Kang, S., \& Lee, H. (2011). Foreign Direct Investment and Deindustrialization. World Economy, 313-329.

Kaya, Y. (2010). Globalization and industrialization in 64 developing countries, 1980-2003. Social Forces, 88(3), $1153-1182$.

Kuznets, S. (1957). Quantitative Aspects of economic growth. Economic Development and cultural Change, 3111.

Leonardi, R., Nanetti, R. Y., \& Putnam, R. D. (2001). Making democracy work: Civic traditions in modern Italy. Princeton university press Princeton, NJ.

Lewis, W. A. (1954). Economic development with unlimited supplies of labour.

McGrath, S., Ramsarup, P., Zeelen, J., Wedekind, V., Allais, S., Lotz-Sisitka, H., Monk, D., Openjuru, G., \& Russon, J.-A. (2020). Vocational education and training for African development: A literature review. Journal of Vocational Education \& Training, $72(4), 465$ - 487. https://doi.org/10.1080/13636820.2019.1679969

McMillan, M. S., \& Rodrik, D. (2011). Globalization, structural change and productivity growth. National Bureau of Economic Research.

Mupimpila, C., \& Narayana, N. (2009). The role of vocational education and technical training in economic growth : A case of Botswana. International Journal of Education Economics and Development, 1(1), 3-13.

Murphy, K. M., Shleifer, A., \& Vishny, R. W. (1989). Industrialization and the big push. Journal of political economy, 97(5), 1003-1026.

Myrdal, G., \& Sitohang, P. (1957). Economic theory and under-developed regions.

Newman, C. (Éd.). (2016). Manufacturing transformation: Comparative studies of industrial development in Africa and emerging Asia (First editon). Oxford University Press.

Oke, A., \& Fernandes, F. A. P. (2020). Innovations in teaching and learning: Exploring the perceptions of the education sector on the 4th industrial revolution (4IR). Journal of Open Innovation: Technology, Market, and Complexity, 6(2), 31.

Oketch, M. (2014). Education policy, vocational training, and the youth in Sub-Saharan Africa. World Institute for Development Economic Research (UNU-WIDER).

Ongo Nkoa, B. E. (2016). Investissements directs étrangers et industrialisation de l'Afrique : Un nouveau regard. Innovations, 51(3), 173. https://doi.org/10.3917/inno.051.0173

Oyelaran-Oyeyinka, B., \& Lal, K. (2016). Structural Transformation and Economic Development : Cross regional analysis of industrialization and urbanization. Taylor \& Francis.

Pack, H. (2002). Africa's declining productivity : Evidence from Tanzania. mimeo, University of Pennsylvania.

Page, J. (2012). Can Africa Industrialise? Journal of African Economies, 21(suppl_2), ii86-ii124.

Psacharopoulos, G. (1994). Returns to investment in education : A global update. World development, 22(9), 1325 $-1343$.

Psacharopoulos, G., \& Loxley, W. A. (1985). Diversified secondary education and development: Evidence from Colombia and Tanzania. Published for the World Bank.

Ramaswany, R., \& Rowthorn, B. (1997). Deindustrialization: Its Causes and Implications. INTERNATIONAL MONETARY FUND. https://doi.org/10.5089/9781557756435.051

Rodrik, D. (2013). Unconditional convergence in manufacturing. Quaterly Journal of Economics, 128(1), 165204.

Rodrik, D. (2015). Premature deindustrialization. Journal of Economic Growth, 21(1), 1-33.

Rosenstein-Rodan, P. N. (1943). Problems of industrialisation of eastern and south-eastern Europe. The economic journal, 53(210/211), 202-211. 
Rosina, H., Virgantina, V., Ayyash, Y., Dwiyanti, V., \& Boonsong, S. (2021). Vocational Education Curriculum : Between Vocational Education and Industrial Needs. ASEAN Journal of Science and Engineering Education, 1(2), 105-110.

Schultz, T. (1963). The Economics Value of Education. New York and London. Columbia. University Press.

Silliman, M., \& Virtanen, H. (2022). Labor Market Returns to Vocational Secondary Education. American Economic Journal: Applied Economics, 14(1), 197-224. https://doi.org/10.1257/app.20190782

Totouom, A., Kaffo, H. F., \& Sundjo, F. (2019). Structural transformation of Sub-Saharan Africa : Does the quality of institutions matter in its industrialization process? Région et Développement, 50, 18.

UNECA. (2016). Measuring corruption in Africa: The international dimension matters. African report governance IV.

Volger, H. (Éd.). (2010). UNIDO - United Nations Industrial Development Organization. In A Concise Encyclopedia of the United Nations (p. 732-732). Brill | Nijhoff. https://doi.org/10.1163/ej.9789004180048.i962.645

\section{Appendices}

Appendix 1. Ranking of sample countries by region

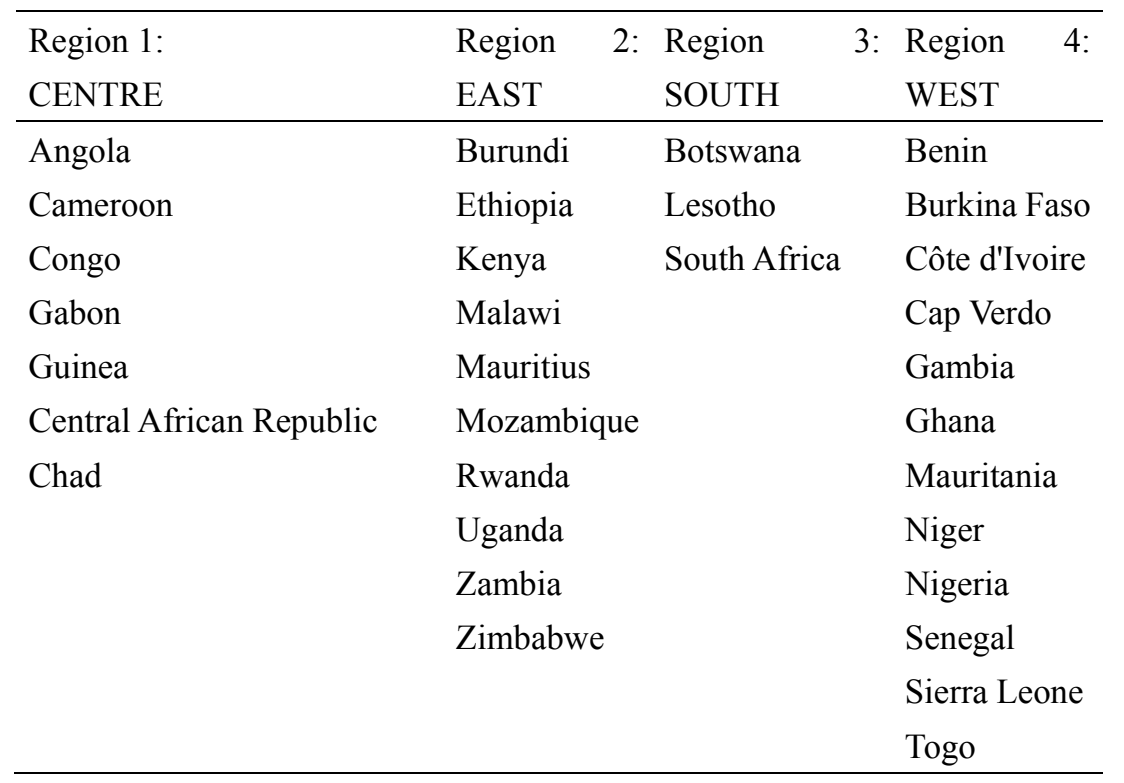

Appendix 2: The EFI has five different components all ranking from 0 to 10 they are: (i) the Government Size Index (GVZ), (ii) the Legal Structure and Security of Property Rights Index (LEG), (iii) the Sound Money Index (SMN), (iv) the Freedom of International Trade Index (FRT) and (v) the Credit, Labour and Business Regulation Index (REG).

\section{Copyrights}

Copyright for this article is retained by the author(s), with first publication rights granted to the journal.

This is an open-access article distributed under the terms and conditions of the Creative Commons Attribution license (http://creativecommons.org/licenses/by/4.0/). 